\title{
A study to use hematological and biochemical parameters as a key in the diagnosis of acute mesenteric ischemia
}

\author{
Akut mezenterik iskemi tanısında hematolojik ve biyokimyasal parametrelerin bir anahtar olarak \\ kullanımına yönelik bir çalışma
}

\author{
Mikail Çakır ${ }^{1}$, Doğan Yıldırım ${ }^{1}$, Ahmet Kocakuşak ${ }^{1}$, Okan Murat Aktürk ${ }^{1}$, Leyla Tigrel ${ }^{1}$
}

\section{Abstract}

Aim: Acute mesenteric ischemia is still fatal in 59-92\% of cases. Delay in diagnosis of acute mesenteric ischemia can cause dramatic increase in morbidity and mortality rates. However several diagnostic and disease related factors have been widely studied. Controversy still remains. In this study, we evaluated hematological and biochemical parameters in patients with acute mesenteric ischemia.

Methods: 46 patients (study group) who underwent emergent surgery for acute mesenteric ischemia and 46 patients (control group) operated for acute abdomen with another etiology other than acute mesenteric ischemia and internalized to intensive care unit were included in this study. Medical records and clinical data of acute mesenteric ischemia patients between January 2008 and December 2014 were evaluated with regard to 8 parameters; age, amylase, white blood cell count, mean platelet volume, creatine kinase, lactate dehydrogenase, lactate and D-dimer. These parameters were selected for their increased levels in acute mesenteric ischemia patients according to many published medical studies. Control group was formed randomly from patients followed in intensive care unit for their co-morbidities after acute abdomen operation in the same period. Gender was included in the table but was not taken into account as a parameter for the study.

Results: Mean values of age, white blood cell count, creatine kinase, lactate dehydrogenase, lactate and D-dime were significantly higher in acute mesenteric ischemia group than the control group. Mean platelet volume was significantly lower in acute mesenteric ischemia group. The $\mathrm{p}$ values were for age $(\mathrm{p}=0.009)$, for amylase $(0.475)$, for white blood cell $(\mathrm{p}=0.001)$ for mean platelet volume $(0=0.001)$, for creatinine kinase $(\mathrm{p}=0.017)$, for lactate dehydrogenase $(\mathrm{p}=0.001)$, for lactate $(\mathrm{p}=0.001)$, for $\mathrm{D}$-dimer $(\mathrm{p}=0.001)$ respectively.

Conclusion: White blood cell count, creatine kinase, lactate dehydrogenase, lactate and D-dimer levels increase mean platelet volume decrease in acute mesenteric ischemia patients significantly.

Keywords: Acute mesenteric ischemia, hematological parameters, biochemical parameters.

Öz

Amaç: Akut mezenterik iskemi \%59-92 oranından ölümcül seyretmektedir. Tanıda gecikme morbidite ve mortalitede ciddi artışa sebep olabilmektedir. Bu konuyla ilgili pek çok tanısal çalışma yapılmıştır. Bu çalışmada, akut mezenterik iskemisi olan hastalarda hematolojik ve laboratuar parametrelerin değerlendirilmesi amaçlandı.

Yöntem: Bu çalışmaya akut mezenterik iskemi tanısıyla acil cerrahiye giden 46 hasta ile akut abdomen sebebiyle opere edilen ve yoğun bakım ünitesine alınan 46 hasta dahil edildi. Ocak 2008 ve Aralık 2014 tarihleri arasında akut mezenterik iskemi hastalarının dosyaları tarandı. Sekiz parametre ile ilgili tablolar oluşturuldu amilaz, beyaz küre sayısı, ortalama trombosit hacmi, kreatinin kinaz, laktat dehidrogenez, laktat ve D-dimer. Bu parametreler daha önce çeșitli çalıșmalarda akut mezenterik iskemide yükselmiș olarak bulunan parametrelerdir Kontrol grubu aynı dönemde akut abdomen sebebiyle opere edildikten sonra yoğun bakıma alınmış olan hastalardan randomize olarak seçildi. Cinsiyet tablolarda yer almakla birlikte bu çalışmada bir parametre olarak kullanılmadi.

Bulgular: Ortalama yaş, amilaz düzeyi, beyaz küre sayısı, kreatinin kinaz, laktat dehidrogenez, laktat ve D-dimer akut mezenterik iskemi grubunda kontrol grubuna oranla daha yüksek olarak tespit edildi. Ortalama trombosi volumu akut mezenter iskemisi grubunda istatistiksel olarak anlamlı derecede daha düşüktü. P değerleri yaş için 0,009 , amilaz $\mathrm{p}=0,475$, beyaz küre sayısı için 0,001 , kreatinin kinaz için 0,017 , laktat dehidrogenaz için 0,001 , laktat içim 0,001 ve D-dimer için 0,001 idi.

Sonuç: Akut mezenterik iskemi hastalarında beyaz küre sayısı, kreatin kinaz, laktat dehidrogenez, laktat, D dimer sayıları artarken ortalama trombosit hacmi belirgin olarak azalmaktadır.

Anahtar kelimeler: akut mezenterik iskemi, kan parametreleri, D-dimer
1 Department of General Surgery, Haseki Training and Reseach Hospital, Istanbul, Turkey.

Ethics Committee Approval: The study wass approved by the local ethical authority. Etik Kurul Onayı: Çalışma lokal etik komite tarafindan onaylanmıştır.

Conflict of Interest: No conflict of interest was declared by the authors.

Çıkar Çatışması: Yazarlar çıkar çatışması bildirmemişlerdir.

Financial Disclosure: The authors declared that this study has received no financial support.

Finansal Destek: Yazarlar bu çalıșma için finansal destek almadıklarını beyan etmişlerdir.

Gelis Tarihi / Received: 11.04.2018

Kabul Tarihi / Accepted: 05.07.2018

Yayın Tarihi / Published: 20.07.2018

Sorumlu yazar / Corresponding author:

Okan Murat Akturk

Haseki Training and Reseach Hospital, General Surgery Clinic, Suphi Paşa Sokak 5/4, Haseki Sultan Mahallesi, Fatih, Istanbul, Turkey. Phone: 905323206983

e-mail: omakturk@gmail.com

Copyright $($ C ACEM 


\section{Introduction}

Acute mesenteric ischemia (AMI) accounts for approximately $1 \%$ of all causes of acute abdomen and is associated with very poor prognosis. The mortality rate is between 59\% and 92\% [1]. Although diagnostic methods have advanced in recent years, laboratory findings are still an area of investigation. A 24-hour delay in diagnosis and surgical intervention reduces the survival rate of AMI patients by $20 \%$ [2]. Physical examination findings in emergency unit are similar to other causes of acute abdomen. Laboratory findings are usually non-specific in routine examination. In cases with a strong suspicion for AMI, more specific markers such as lactate, lactate dehydrogenase (LDH) and D-dimer may be studied. Duplex ultrasonography and computerized tomography angiography are useful but not specific for distal vascular pathologies [3,4]. Angiography performed by interventional radiology is the best imaging method but most of the emergency units don't have a possibility of angiography. From the literature review there is no sensitive and specific laboratory test for an early diagnosis of bowel infarction and the diagnosis is often delayed. Therefore blood measurements of various hematologic and biochemical markers are widely studied. The most popular ones are white blood cell (WBC) count [1], creatine kinase (CK), mean platelet volume (MPV) [5], neutrophil to lymphocyte ratio (NLR)[6-8], red cell distribution width (RDW)[7], lactate dehydrogenase (LDH), lactate, D-dimer, procalcitonin, phosphorus $[1,2,8]$. AMI is an acute inflammatory process depending on ischemia. Bacterial infiltration of intestinal wall causes sepsis and sepsis related biomarkers such as C-reactive protein, procalcitonin, MPV and neutrophilia are used as indicators of inflammation. The main etiologic factors are embolic or thrombotic arterial occlusion in $60-70 \%$ of cases, non-occlusive ischemia and infarction in $20-30 \%$ of cases and mesenteric venous thrombosis in $5-10 \%$ [1]. Since the delay in diagnosis increases mortality rates, measurement of several biomarkers in blood may give important clues for diagnosis.

The aim of this study was to evaluate the association of WBC, CK, LDH, lactate and D-dimer in patients with AMI with regard to their diagnostic efficacy.

\section{Materials and Methods}

From January 1st 2008 to December 31st 2014; 46 patients operated for AMI at Haseki Research and Training Hospital Emergency General Surgery Clinic were analyzed retrospectively. The study was approved by Haseki Research and Training Hospital Ethical Committee with a number of 17R/2018 with confirmation of Helsinki declaration. Written consent of the patients for using their clinical data was taken before the operation. Control group was formed from the patients operated for acute abdomen other than AMI and internalized to intensive care unit (ICU) for their co-morbidities. A total of 8 parameters (age, gender, amylase, WBC, CK, LDH, lactate, D-dimer) were recorded for 2 groups. Imaging modalities, operation findings, survivors and non-survivors were also evaluated. Control group was chosen randomly from the patients operated for acute abdomen in ICU. To provide similarity between groups, all of the patients in the control group were chosen randomly from the patients operated for acute abdomen and sent to intensive care unit due to co-morbidities in the same period. All of the patients with AMI were followed in the intensive care unit (ICU) after the operation.

\section{Statistical analysis}

Detection of AMI in the study group was regarded as the main outcome. All statistics were performed using SPSS 20.0 for Windows (SPSS Inc, Chicago, IL, USA). Normallydistributed continuous variables were expressed as mean \pm standard deviations (SD) Categorical variables were expressed as frequencies and percentages.

The patients with and without AMI were regarded as AMI and control groups, respectively. Patients' demographics (age and sex) and laboratory parameters (WBC (103/mm3), MPV (fentoliter), amylase (U/L), LDH (U/L), CK (IU/L), lactate $(\mathrm{mg} / \mathrm{dL}), \mathrm{D}$-dimer $(\mu \mathrm{g} / \mathrm{L}))$ were analyzed based on this grouping. Fischer's exact test and Mann-Whitney $U$ test were used for normally and non-normally distributed parameters, respectively. Categorical variables were analyzed using Pearson's chi square test.

The patients were analyzed based on the serum levels of the parameters as increased or non-increased according to the upper normal levels reported by the laboratory and analyzed by using Pearson's chi square test (Table 1).

The analysis of receiver operating characteristics (ROC) curve associated with the area under the curve (AUC) was used to discover the optimal cut-off values with their specificity and sensitivity numbers to predict the development of AMI.

All tests were two sided and p value less than 0.05 were considered statistically significant.

Table 1. The upper and lower limits of laboratory paramaters

\begin{tabular}{lccc} 
Laboratory parameter & Lower limits & Upper limits & Unit \\
\hline Amylase & 28 & 100 & $\mathrm{U} / \mathrm{L}$ \\
WBC & 4.320 & 10.200 & $10^{3} / \mathrm{mm}^{3}$ \\
MPV & 6.8 & 10.8 & $\mathrm{Fl}(\mathrm{fentolitre})$ \\
CK & & $<171$ & $\mathrm{IU} / \mathrm{L}$ \\
LDH & & $<217$ & $\mathrm{U} / \mathrm{L}$ \\
Lactate & 0.5 & 1.6 & $\mathrm{mg} / \mathrm{dL}$ \\
D-dimer & & $<500$ & $\mu \mathrm{g} / \mathrm{L}$ \\
\hline : White blood cell, MPV: Mean platelet volume, CK: Creatine kinase, $\mathrm{LDH}$ : Lactate
\end{tabular}

WBC: White b dehydrogenase

\section{Results}

A total of 46 AMI and 46 control patients were enrolled. There were $2247.8 \%$ ) male and 24 (52.2\%) female patients in AMI group. There were 24 (52.2\%) male and 22 $(47.8 \%)$ female patients in control group. Male/female ratio was similar in groups. Gender difference wasn't important statistically. Mean ages were 67.2 and 60.4 years for AMI and control groups respectively and age was significantly higher in AMI group $(p=0.009)$. Amylase levels in both groups were not significantly different, $(\mathrm{p}=0.475)$. WBC $\quad(\mathrm{p}=0.001), \quad \mathrm{CK}$ $(\mathrm{p}=0.017), \mathrm{LDH}(\mathrm{p}=0.001)$, lactate $(\mathrm{p}=0.001), \mathrm{D}$-dimer $(\mathrm{p}=0.001)$ mean levels were significantly higher in AMI patients than control group patients. MPV mean values were 9.6 \pm 2.59 fentoliter (fL) in AMI group and $10.4 \pm 1.3 \mathrm{fL}$ in control group (Table 2).

Table 2. Comparison of parameters in regard to the groups.

\begin{tabular}{lccccc}
\multicolumn{3}{c}{ Mesenteric Ischemia } & \multicolumn{5}{c}{ Control } \\
\hline Male & $\mathrm{n}$ & $\%$ & $\mathrm{n}$ & $\%$ \\
Female & 22 & 47.8 & 24 & 52.2 & \\
& 24 & 52.2 & 22 & 47.8 & \\
\hline Age & Mean \pm SD & Median & Mean \pm SD & Median & $\mathrm{p}$ \\
Amylase & $110.4 \pm 104.1$ & 71.5 & $60.4 \pm 8.6$ & 59.5 & 0.009 \\
WBC & $17365.2 \pm 7769.8$ & 15850 & $7428.9 \pm 2169.6$ & 7325 & 0.001 \\
MPV & $9.6 \pm 2.5$ & 9.1 & $10.4 \pm 1.3$ & 10.1 & 0.001 \\
CK & $396.9 \pm 680.6$ & 105.5 & $91.6 \pm 52.3$ & 78 & 0.017 \\
LDH & $474.3 \pm 282.3$ & 386.5 & $191.8 \pm 37.8$ & 185.6 & 0.001 \\
Lactate & $6.6 \pm 2.8$ & 6.6 & $0.8 \pm 0.4$ & 0.8 & 0.001 \\
D-dimer & $1316.4 \pm 362.4$ & 1341 & $346.8 \pm 94.4$ & 355 & 0.001 \\
\hline WC: White blood cell, MPV: Mean platelet volume, CK: Creatine kinase, LDH: Lactate
\end{tabular}

dehydrogenase 
Five parameters (WBC, LDH, CK, lactate, D-dimer) increased significantly in blood of AMI patients. The frequencies of elevated values were detected as cumulative percentages for amylase in $68(73.9 \%)$, for WBC in $47(51.1 \%$ ), for MPV in $75(81.5 \%)$, for $\mathrm{CK}$ in $70(76.1 \%)$, for $\mathrm{LDH}$ in $50(54.3 \%)$, for lactate in $47(51.1 \%)$ for D-dimer in $45(48.9 \%)$ of all patients $(\mathrm{n}=92)$. It was seen that MPV increase is more prominent in acute abdomen patients other than AMI. There was no significant relationship between the parameters evaluated in AMI (Table 3).

Table 3. Mesenteric ischemia and relationship among the parameters.

\begin{tabular}{llccccccr} 
& & Age & Amylase & WBC & MPV & CK & LDH & Lactate \\
\hline Amylase & rho & 0.165 & & & & & & \\
& $\mathrm{p}$ & 0.274 & & & & & & \\
WBC & rho & -0.210 & -0.101 & & & & & \\
& $\mathrm{p}$ & 0.161 & 0.503 & & & & & \\
MPV & rho & 0.025 & 0.270 & 0.096 & & & & \\
& $\mathrm{p}$ & 0.871 & 0.069 & 0.525 & & & & \\
CK & rho & -0.209 & -0.056 & 0.051 & -0.242 & & & \\
& $\mathrm{p}$ & 0.164 & 0.714 & 0.736 & 0.105 & & & \\
LDH & rho & 0.122 & 0.150 & 0.245 & -0.164 & 0.108 & & \\
& $\mathrm{p}$ & 0.420 & 0.320 & 0.100 & 0.277 & 0.476 & & \\
Lactate & rho & 0.128 & -0.014 & -0.046 & 0.055 & -0.087 & -0.004 & \\
& $\mathrm{p}$ & 0.398 & 0.929 & 0.761 & 0.716 & 0.565 & 0.980 & \\
D-dimer & rho & 0.058 & -0.114 & 0.058 & -0.089 & 0.249 & -0.084 & -0.057 \\
& $\mathrm{p}$ & 0.702 & 0.451 & 0.703 & 0.558 & 0.095 & 0.577 & 0.705 \\
\hline
\end{tabular}

WBC: White blood cell, MPV: Mean platelet volume, CK: Creatine kinase, LDH: Lactate dehydrogenase

The examples of ROC curves for $\mathrm{WBC}$ and lactate are shown in (Table 4,5) (Figure 1,2). Cut-off value of WBC as $11,405103 / \mathrm{mm}^{3}$ revealed "Area Under Curve" value of 0.959 . Similarly, $1.9 \mathrm{mg} / \mathrm{dL}$ cut off value of lactate revealed "Area Under Curve" of 0.994.

Table 4. Interpretation of the curve of the parameters

\begin{tabular}{lccccc} 
Parameter & Area Under Curve & SE & p & \multicolumn{3}{c}{$95 \%$ Confidence Interval } \\
\hline Amylase & 0.542 & 0.065 & 0.475 & 0.416 & 0.671 \\
WBC & 0.959 & 0.019 & 0.001 & 0.922 & 0.997 \\
MPV & 0.737 & 0.051 & 0.001 & 0.655 & 0.855 \\
CK & 0.646 & 0.060 & 0.017 & 0.529 & 0.763 \\
LDH & 0.935 & 0.030 & 0.001 & 0.878 & 0.995 \\
Lactate & 0.994 & 0.007 & 0.001 & 0.981 & 1.000 \\
D-dimer & 1.000 & 0.001 & 0.010 & 0.998 & 1.000 \\
\hline
\end{tabular}

WBC: White blood cell, MPV: Mean platelet volume, CK: Creatine kinase, LDH: Lactate dehydrogenase

Table 5. Cut-off values of the parameters.

\begin{tabular}{lccc} 
& Cut-off value & Sensitivity & 1-Specificity \\
\hline WBC & 11,405 & 0.804 & 0.043 \\
MPV & 9.65 & 0.804 & 0.304 \\
LDH & 213.75 & 0.957 & 0.217 \\
Lactate & 1.9 & 0.978 & 1.000 \\
D-dimer & 481.5 & 1.000 & 0.022 \\
CK & 78.35 & 0.652 & 0.477 \\
\hline
\end{tabular}

WBC: White blood cell, MPV: Mean platelet volume, CK: Creatine kinase, LDH: Lactate dehydrogenase

Other than our main aim of this study, we would like to give also clinical data for these patients and groups. In AMI group CT and CT angiography were the main imaging modality to put the initial diagnosis. According to causes there were arterial occlusion in 34 (73.9\%), venous occlusion in $8(17.4 \%)$ and non-occlusive mesenteric ischemia in $4(8.7 \%)$ of patients, respectively. Ischemia was detected in only the small intestine in $24(52 \%)$ patients, while both the small intestine and colon were ischemic in $22(48 \%)$ patients. The patients underwent resection of ischemic segments except one patient. For this patient revascularization of SMA was performed successfully after open embolectomy. Twenty-seven $(58.7 \%)$ patients died, 19 (41.3\%) patients survived after the operation. Mean ages of patients who died and survived were 71.3 and 61.7 years, respectively. Control group was consisting of patients operated for acute abdomen and internalized to intensive care unit due to comorbidities. 18 (39\%) appendicitis (11 perforated, 7 nonperforated), $7(15 \%)$ peptic ulcer perforation, $11(24 \%)$ incarcerated inguinal hernia (6 with small intestine resection, 5 without resection), 7 (15\%) colorectal tumor perforation (4 resection and anastomosis, 3 resection and ostomy formation), 3 $(7 \%)$ brid ileus were the operation findings (Table 6). Mortality rate for this group was $15.2 \%$.

Table 6. Control Group

\begin{tabular}{lccc} 
& Number & $\%$ & Mortality (\%) \\
\hline Acute Apendicitis (perforated 11, non-perforated 7) & 18 & 39 & 3 \\
Peptic Ulcer Perforation & 7 & 15 & 1 \\
Incarcerated inguinal hernia (resection 6, without resection 5) & 11 & 24 & 1 \\
Colorectal tumor perforation (resection and anastomosis 4, & & & \\
resection and ostomy formation 3) & 7 & 15 & 2 \\
Brid Ileus & 3 & 7 & 0 \\
\hline Total & 46 & 100 & $7(15.2 \%)$ \\
\hline
\end{tabular}

Figure 1. The ROC curve of white blood cell.

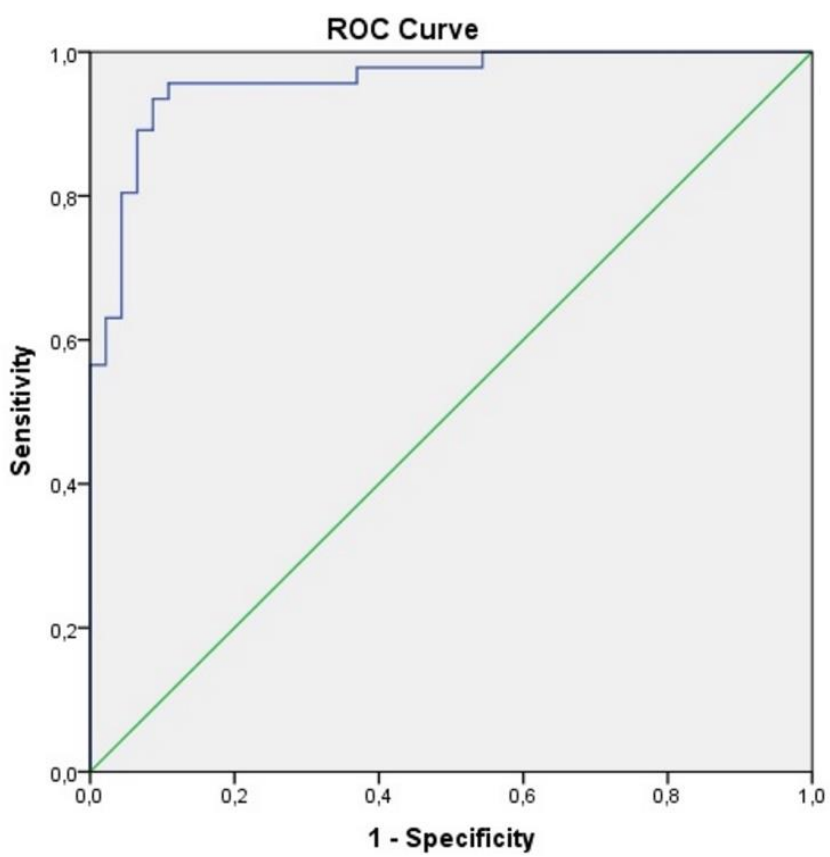

Figure 2. The ROC curve of lactate.

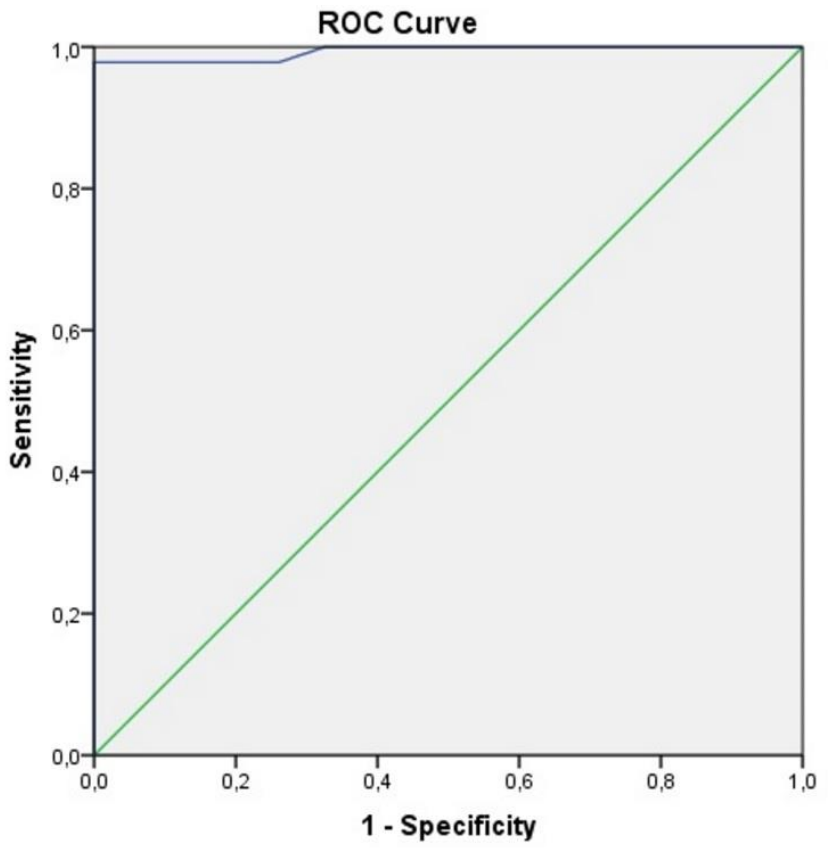

\section{Discussion}

The main pathophysiologic changes in AMI are systemic inflammatory response, bacterial translocation and reperfusion injury. Intestinal wall microcirculation deteriorates, capillary permeability increases and bacterial translocation 
occurs. Progression will finally cause peritonitis and perforation. Early diagnosis, early surgical intervention; resection of necrotic intestinal segments and restoration of blood flow are essential. A high index of suspicion with prompt diagnostic evaluation may reduce the delay prior to surgical intervention. Therefore to find a specific and sensitive biomarker related to AMI is still an area of investigation. Most of retrospective trials suggest some biomarkers to increase in AMI but also add that they are not specific and sensitive because those biomarkers increase in other acute abdomen causes [1, 5, 8, 9, 10]. Concerning this in our study we studied that 5 relatively more increasing parameters in AMI compared with other causes of acute abdomen. These parameters also increase in other causes of acute abdomen. But our results showed that increase is more evident in AMI. The patients with AMI have leukocytosis, metabolic acidosis, an elevated D-dimer and elevated serum lactate, LDH and CK [10, 11]. Increased WBC count exceeding $20 \times 10^{\wedge} 9 / \mathrm{L}$ have been reported but these finding has not been associated with the extent of necrosis or distinguishing AMI from other diagnosis [1, 10]. $\mathrm{CK}$ isoenzyme $\mathrm{BB}$ has been demonstrated in the mucosa and muscularis throughout the entire gastrointestinal system. Isoenzyme CK-BB levels are increasing with intestinal ischemic pathologies [12, 13] but total CK level has not been found to increase in most of studies. In our study total CK was found higher significantly in AMI patients $(p=0.017)$. D-dimer is the one of the most studied parameters in AMI. It is an enzyme degradation product of fibrin that is released during intravascular coagulation and fibrin deposition which may be present in AMI. In most of the studies D-dimer is an important marker showing intestinal ischemia $[14,15]$ and some studies say its level doesn't differ significantly between AMI and other causes of acute abdomen [10]. We found that it is higher in AMI patients $(\mathrm{P}=0.001)$. LDH is also an increasing parameter. Its increase is also controversial. Some studies report that the difference is not significant [1]. In our study LDH increase was found significant on comparison with other acute abdomen causes $(\mathrm{p}=0.001)$. Lactate is associated with late stage mesenteric ischemia with extensive transmural infarction, body tissue hypoperfusion, anabolic metabolism and death [15]. Lactate is elevated after advanced mesenteric damage [6]. But its increase is not specific to AMI. Some studies report that increase in lactate level doesn't differ in AMI compared with other causes of acute abdomen [10, 16]. In our study lactate level was significantly higher in AMI patients $(p=0.001)$. MPV findings were conversely related to literature knowledge. We reviewed several studies reporting MPV increase in AMI patients. MPV value was higher in acute abdomen patients than AMI $[5,9]$.To measure a single parameter is not sufficient to diagnose AMI. These parameters should be evaluated altogether.

Limitation of the study was its retrospective design. Besides, the selection of control group might be biased due to lack of uniformity of criteria for acceptance of patients to ICU.

In conclusion, AMI has still high morbidity and mortality. Diagnostic delay must be prevented by means of laboratory findings and imaging modalities especially computed tomography and computed tomography angiography so that early diagnosis may ensure timely surgery. As in other reported studies, increasing levels of $\mathrm{WBC}, \mathrm{LDH}, \mathrm{CK}$, lactate and Ddimer could help the diagnosis of AMI. Early surgery and proper management will increase survival especially in hospitals with limited radiologic facilities.

\section{References}

1. Paladino NC, Inviati A, Di Paola V, Busuito G, Amodio E, Bonventre S, et al. Predictive factors of mortality in patients with acute mesenteric ischemia. Ann Ital Chir. 2014;85:265-70.

2. Karabulut K, Gul M, Dundar ZD, Cander B, Kurban S, Toy H Diagnostic and prognostic values of procalcitonin and phosphorus in acute mesenteric ischemia. Ulus Travma Cerrahi Derg. 2011;17:193-8.

3. Hamzaoglu I, Ulualp K, Balkan T, Cander B, Kurban S, Toy H. Abdominal emergencies in octogenerians. Ulus Travma Acil Cerrahi Derg. 2000;6:36-8.

4. Demir IE, Ceyhan GO, Friess H. Beyond lactate: Is there a role for serum lactate measurement in diagnosing acute mesenteric ischemia? Dig Surg. 2012;29:226-35.

5. Turkoglu A, Gul M, Oguz A, Bozdağ Z, Ülger BV, Yılmaz A, et al. Mean platelet volume: Is it a predictive parameter in diagnosis of acute mesenteric ischemia? Int Surg. 2015;100:962-5.

6. Aktimur R, Cetinkunar S, Yildirim K, Aktimur SH, Ugurlucan M, Ozlem N. Neutrophil-to-lymphocyte ratio as a diagnostic biomarker for the diagnosis of acute mesenteric ischemia. Euro J Trauma Emerg Surg. 2016;42:363-8

7. Kisaoglu A, Bayramoglu A, Ozogul B, Atac K, Emet M, Atamanalp SS Sensitivity and specificity of red cell distribution width in diagnosing acute mesenteric ischemia in patients with abdominal pain. World $\mathrm{J}$ Surg. 2014;38:2770-6.

8. Tanrikulu Y, Tanrikulu CS, Sabuncuoglu MZ, , Temiz A, Köktürk F, Yalçın B. Diagnostic utility of the neutrophil-lymphocyte ratio in patients with acute mesenteric ischemiaia retrospective cohort study. Ulus Travma Acil Cerrahi Derg. 2016;22:344-9.

9. Altintoprak F, Arslan Y, Yalkin O, Uzunoglu Y, Ozkan OV. Mean platelet volume as a potential prognostic marker in patients with acute mesenteric ischemia-retrospective study. World J Emerg Surg. 2013;8:49.

10. van den Heijkant TC, Aerts BA, Teijink JA, Buurman WA, Luyer MD Challenges in diagnosing mesenteric ischemia. World J Gastroenterol. 2013;19:1338-41.

11. Oldenburg WA, Lau LL, Rodenberg TJ, Edmonds HJ, Burger CD. Acute mesenteric ischemia: a clinical review. Arch Intern Med 2004;164:1054-62.

12. Corke C, Glenister K. Monitoring intestinal ischemia. Crit Care Resusc. 2001;3:176-80.

13. Fried MW, Murthy UK, Hass SR, Oates RP. Creatine kinase isoenzymes in the diagnosis of intestinal infarction. Dig Dis Sci. 1991;36:1589-93.

14. Yang S, Fan X, Ding W, Liu B, Meng J, Wang K, et al. D-dimer as an early marker of severity in patients with acute superior mesenteric venous thrombosis. Medicine (Baltimore). 2014;93: e270.

15. Acosta S, Nilsson T. Current status on plasma biomarkers for acute mesenteric ischemia. J Thromb Thrombolysis. 2012;33:355-61.

16. Studer P, Vaucher A, Candinas D, Schnüriger B. The value of serial serum lactate measurements in predicting the extent of ischemic bowel and outcome of patients suffering acute mesenteric ischemia. J Gastrointest Surg. 2015;19:751-5. 